\title{
On Perlite and on Railroads in Colorado
}

\author{
Stephen J. Clarson
}

Received: 1 July 2013 / Accepted: 12 August 2013 / Published online: 28 September 2013

(C) Springer Science+Business Media Dordrecht 2013

\begin{abstract}
The journal SILICON covers all aspects of silicon-based materials. I have carried out research on silicon since 1979 and yet I am constantly amazed at the places that I come across references to this fine element and its compounds. This EDITORIAL is concerned with a citation on perlite and its production and transportation in Colorado, USA. The reference to perlite was located in a book that I had purchased in a public library "clearance" sale.
\end{abstract}

Keywords Perlite · Rhyolite · Antonito · Colorado · Cumbres \& Toltec Scenic Railroad

\section{Perlite in Antonito, Colorado, USA}

In June of 2013 I was at a public library "surplus" book sale in Cincinnati, Ohio. At this event one could fill a bag with books or other library materials for a mere ten dollars. For a declared bibliophile this was tremendous fun [1]. One of the books that I placed in my bag was Ticket to Toltec by the American geologist Doris B. Osterwald (see Fig. 1) [2]. I chose to open and read this book first and, much to my

S. J. Clarson $(\bowtie)$

Department of Mechanical and Materials Engineering, and The Polymer Research Centre, The University of Cincinnati, Cincinnati, OH 45221-0072, USA

e-mail: stephen.clarson@uc.edu surprise, it contained a reference to silicon $(\mathrm{Si})$ and, more specifically, to perlite.

Reading this book, I came upon the following passage on the perlite industry in Colorado [3].

"In addition to the economic impact the railroads have on the valley, the perlite processing plant south of Antonito is an important industry for the area. Perlite is a special type of silicic volcanic rock (rhyolite), similar in composition to granite, but contains an additional 2 to 5 percent water. When perlite is heated to $1,500{ }^{\circ} \mathrm{F}\left(820^{\circ} \mathrm{C}\right)$, the water becomes volatile and the rock literally explodes. A nickname is volcanic "popcorn." Open-pit mines are near No Agua, New Mexico. The rock is trucked to the plant where it is heated, crushed, sized, and blended for shipment all over the United States. The resulting material is used as a lightweight aggregate in cement, as a substitute for sand in plaster, and in oil well drilling. It can also be used as a filtering agent in the manufacture of drugs, chemicals, and as a sterile material in which plants can be grown."

In the book, Doris B. Osterwald gives an eleven page summary of the geologic history of Colorado and of New Mexico and a one page glossary of geologic terms. The glossary section includes the following description of rhyolite [4].

"Light-colored extrusive volcanic (igneous) rocks containing large crystals (phenocrysts) of quartz and 


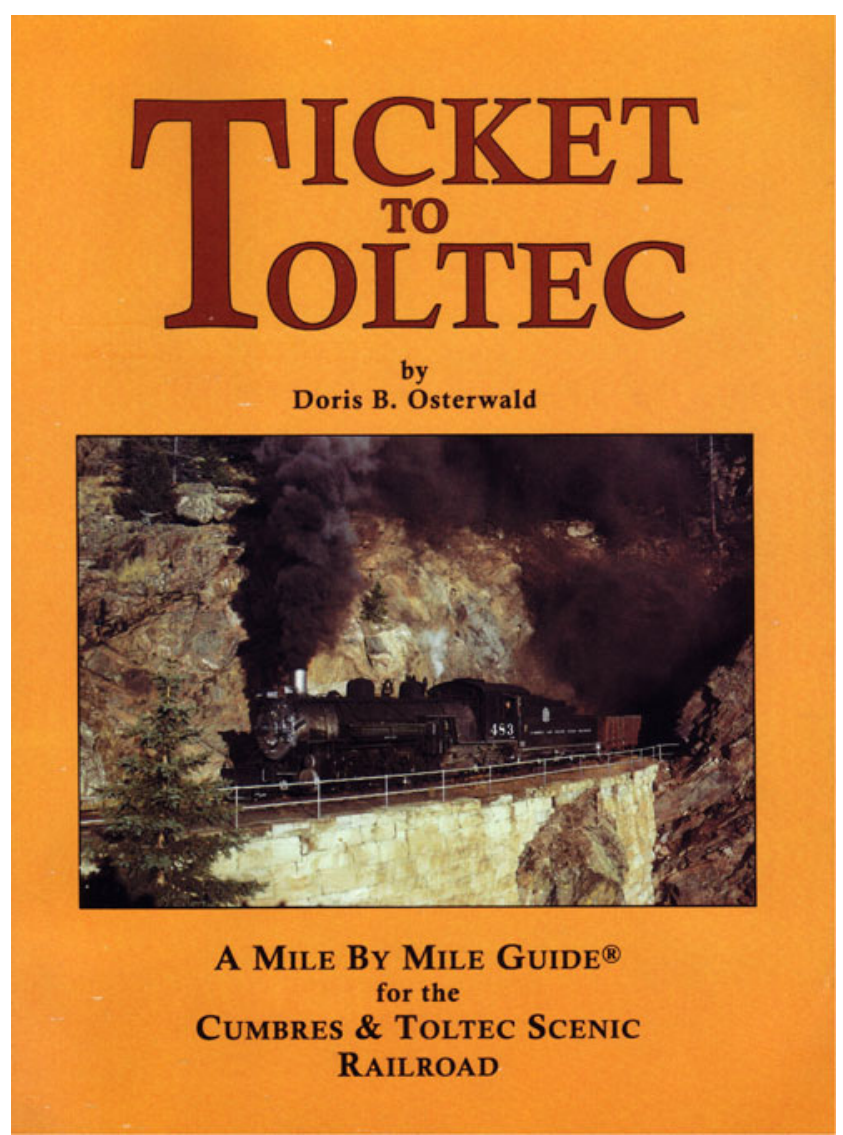

Fig. 1 Ticket to Toltec by the American geologist Doris B. Osterwald [2]

alkali feldspar in a glassy to very fine-grained matrix. Most rhyolites show flow textures."

The geologic history section states the following on the local geologic history of rhyolite [5].

"Numerous ash-flow sheets are recognized throughout the San Juan Mountains. However, the activity that formed these rocks ceased about 23 million years ago, and was succeeded by relatively quiet eruptions of alkali basalt and rhyolite volcanic rocks. These quiet eruptions stopped about 4 million years ago."

\section{The Early Railroads of Colorado, USA}

The early railroads in the state of Colorado were important to the various activities related to silver, gold and other metals - such as iron. In their book on the history of Colorado, Klinglesmith and Soran state the following [6].

"By 1896, Colorado had more than 4,700 miles of track operated by 15 railroads, employing some 12,000 workers."

As we move forward in time to current railroading practices, the Cumbres \& Toltec Scenic Railroad is a spectacular sixty four miles of the Rio Grande railroad's narrow gauge San Juan main line [7].

\section{Concluding Remarks}

Quite, quite wonderful writing by Doris B. Osterwald. The book Ticket to Toltec far exceeds the standard of material that is typically presented on preserved railroads. So if you are interested in rocks \& minerals, geology, preserved (steam) railroads and even silicon and its compounds, then this book is well worth reading.

Perhaps it is time for me to set out on another visit to the mountains and valleys of Colorado. A good time to do this might be after (or before) the American Chemical Society (ACS) national meeting in Denver, CO in the Spring of 2015.

\section{References}

1. Clarson SJ (2011) Silicon 3(3):103-107

2. Osterwald DB (1992) Ticket to Toltec: a mile by mile guide for the Cumbres \& Toltec Scenic Railroad, 2nd edn. Western Guideways Ltd., Lakewood, CO

3. Reference 2, p 14

4. Reference $2, \mathrm{p} 121$

5. Reference 2, p 111

6. Klinglesmith D, Soran P (1988) Colorado: a history in photographs. Altitude Publishing Ltd., Canmore, AB, p 29

7. Wiatrowski C (2002) Railroads of Colorado. Voyager Press Inc., Stillwater, MN, pp 141-153 